\title{
The application of catalase for the elimination of hydrogen peroxide residues after bleaching of cotton fabrics
}

\author{
ALEXANDRA M. AMORIM, MARCELO D. G. GASQUES, JÜRGEN ANDREAUS and MAURO SCHARF \\ Department of Chemistry, Universidade Regional de Blumenau, 89010.971 - Blumenau- SC - Brazil \\ Manuscript received on February 19, 2001; accepted for publication on April 27, 2002; \\ presented by FERNANDO GALEMBECK
}

\begin{abstract}
Results of dyeing of cotton fabrics with a bifunctional reactive dye were significantly improved when the fabric after bleaching with hydrogen peroxide was treated with catalase for the elimination of hydrogen peroxide residues from the fabrics. Compared to processes with a varying number of washing steps, with and without commercial reducing agents, the consumption of water could be significantly reduced, without altering the final color shade.
\end{abstract}

Key words: catalase, peroxide bleaching, cotton fabrics, textile chemistry, reactive dye, dyeing.

\section{INTRODUCTION}

In the last years biotechnological processes are gradually invading traditional industries like the textile industry. In some cases they are substituting traditional processes, in other cases biotechnological products are used to produce new product properties. The principal advantages are associated to less severe reaction conditions, lower processing temperatures and non-toxic and biodegradable products. Due to their nature, enzymes increase selectively and significantly the reaction rate of a series of specific reactions (Vitolo and Filho 1995).

In today's textile industry the removal of starch sizes from cotton fabrics with amylases is a standard procedure and cellulases are indispensable for the finishing of fabrics made from cellulosic fibers like stone washing of denim garments or biopolishing (Cavaco-Paulo 1998, Andreaus et al. 2000). The application of pectinases for biobleaching of cotton

Correspondence to: Mauro Scharf

E-mail: mscharf@furb.br
(Buschle-Diller et al. 1998), proteases for wool processing (Heine and Hocke 1995, Bishop et al. 1998), and catalases for hydrogen peroxide removal is still under investigation, but commercial products are already available (Pacheco 1998, Durán and Durán 2000).

Reactive dyes of the (Monochlor- and Dichlor-) triazinyl or vinylsulfone type are substantive to cellulosic fibers under neutral conditions but react under alkaline conditions with the hydroxyl groups forming covalent bonds. Depending on their reactivity they react to a certain extent with water. Dye hydrolysis is one of the main reasons for dye losses and problems with color differences in dyeing. Hydrolyzed dye molecules are still substantive to the cellulose, but cannot form covalent bonds with the fiber. They will be removed in posterior washing steps and diminish color fastness (Trotman 1990).

The bleaching with hydrogen peroxide is a fundamental stage that precedes dyeing of cotton fabrics. Hydrogen peroxide as an oxidizing agent leads 
to degradation of reactive dyes (Uygur 1997, 2001) and may increase dye hydrolysis so that remaining peroxide residues on the fabric have a negative influence on the result of dyeing (Tzanov et al. 2001a). Thus residues from bleaching baths must be removed from fabric and machinery before adding the dye. Usually successive washes of the fabric with water or chemical reducers diminish the residual bleaching agent concentration and improve dyeing. However, this involves the use of a big volume of water, a longer process time or the use of chemical products noxious to the environment, resulting in additional costs and the generation of more effluents. An alternative to decrease the consumption of water, energy and time is the use of catalases, which catalyze the decomposition of hydrogen peroxide

$$
\mathrm{H}_{2} \mathrm{O}_{2} \rightarrow \mathrm{H}_{2} \mathrm{O}+1 / 2 \mathrm{O}_{2}
$$

and thus the elimination of its residues on cotton fabrics originated from the bleaching process (Schmidt 1995).

In a recent work Tzanov et al. (2001a) investigated the possibilities of dyeing with catalasetreated bleaching baths. Despite of the absence of peroxide in the catalase treated bleaching baths color differences to conventionally dyed fabrics were unacceptable. In continuation to their study (Tzanov et al. 2001b) they showed that results may be attributed to temperature-dependent dye-enzyme interactions and to the complexity of the bleaching bath composition.

In the present work we studied the use of a catalase for the elimination of hydrogen peroxide residues originating from the bleaching process of cotton and its influence on dyeing with a bifunctional reactive dye of the monofluortriazinyl type. Results are compared in terms of effectiveness and viability with data obtained using chemical reducing agents and / or successive washes with water.

\section{MATERIALS AND METHODS}

Pieces of knitted cotton fabrics $(20 \times 20 \mathrm{~cm}, 6.50 \mathrm{~g})$ were bleached with hydrogen peroxide in a typical bleaching bath $(0.5 \mathrm{~g} / \mathrm{L}$ Sidertex SQ69 as sequestering agent, $0.5 \mathrm{~g} / \mathrm{L}$ Sidertex DS205 as complexing and dispersing agent, $1.0 \mathrm{~g} / \mathrm{L}$ Sidertex U35 as wetting agent, $4 \mathrm{~mL} / \mathrm{L} \mathrm{NaOH} 50 \%$ and $5 \mathrm{~mL} / \mathrm{L} \mathrm{H}_{2} \mathrm{O}_{2}$ $50 \%$ (commercial)) at a liquor ratio $=1: 15$. The bleaching bath was kept 5 minutes at $40^{\circ} \mathrm{C}$, heated up to $90^{\circ} \mathrm{C}$ during 15 minutes and kept during 30 minutes at $90^{\circ} \mathrm{C}$.

After draining the bleaching bath, fabrics were submitted to different treatments for the elimination of peroxide residues from the fabric:

0-2 washes before dyeing

0-2 washes + adding a commercial chemical reducer to the dyeing bath

0-2 washes + adding the catalase to the dyeing bath

The washing steps ( 0 -2 times) before dyeing fabrics were carried out with distilled water at a liquor ratio of $1: 15$

The commercial chemical reducing agent ( 0.8 $\mathrm{g} / \mathrm{L}$, kindly supplied by Quimisa) and the catalase ( $0.4 \mathrm{~g} / \mathrm{L}$; kindly supplied by Novo Nordisk) were added to the dye bath in the beginning of the dyeing procedure. Fabrics were dyed with $1 \%$ o.w.f. (on weight fabric) of the reactive dye Cibacrone Red FN$\mathrm{R}$. The dye bath containing the dye, $0.5 \mathrm{~g} / \mathrm{L} \mathrm{NaCl}$, and $6.0 \mathrm{~g} / \mathrm{L}$ of a sequestering agent was heated up within 10 minutes to $60^{\circ}$ and held at that temperature for 50 minutes. $30 \mathrm{~g} / \mathrm{L} \mathrm{Na}_{2} \mathrm{CO}_{3}$ were added after 20 minutes to start the reaction between dye and cellulose.

In a second set of experiments the influence of enzyme concentration (0.4-0.6 g/L) temperature $\left(25,40\right.$ and $\left.50^{\circ} \mathrm{C}\right)$ and treatment time $(10,20$ and 40 minutes) was investigated. Bleaching, washing and dyeing experiments were carried out in test tubes on a KIMAK dyeing machine. Color differences and color intensity (K/S) of the dyed samples were measured at $560 \mathrm{~nm}$ with an Optronik Reflectance Spectrophotometer (data measurement program Colormes Version: 5.3, model 1996). All 
experiments were executed in triplicate. Commercial products were used without further purification.

\section{RESULTS AND DISCUSSION}

Fabrics dyed without previous treatment after bleaching for the elimination of the peroxide residues presented low color yields and were used as a reference in the color measurements. All other swatches are compared to these samples, so that high color differences $(\Delta \mathrm{E})$ mean a more intense color after dyeing. With successive washes or the use of the catalase or the chemical reducer much better results were obtained (Figure 1). When added directly to the dyeing bath without previous washing, the catalase and the chemical reducer showed to be efficient in the elimination of the peroxide residues and improved significantly the color yield. The introduction of one wash-step before the treatment with the catalase or the chemical reducer and dyeing increased the color yield noticeable, whereas an additional second wash-step just showed a slight improvement.

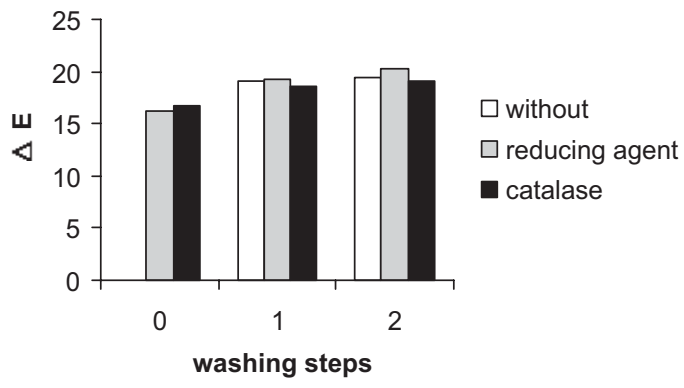

Fig. 1 - Color difference obtained by dyeing cotton knitted fabrics with Cibacrone Red after different treatments following bleaching.

Results shown in Figure 1 demonstrate that dyeing may be carried without any washing step before dyeing by adding a catalase or a chemical reducer directly to the dyeing bath.

Anyhow, results have to be optimized since color differences are accepted only up to values of about 1,5 .

Since the increase of $\mathrm{pH}$ during dyeing (addi- tion of sodium carbonate) leads to deactivation and denaturing of the enzyme, there is not any need for its removal from the bath, which means that the enzyme can be applied directly in the dyeing bath.

The treatment with the enzyme catalase presented color yields similar to the treatments with the chemical reducer and successive washes, with the advantage of less water consumption and avoiding the use of noxious chemicals. The physical and chemical properties of the final product did not show any significant alterations due to the enzymatic treatment. Longer processing times and temperatures around $50^{\circ} \mathrm{C}$ increased the efficiency of the enzymatic treatment, and improved the result of the same dyeing procedure. The maximum efficiency of the enzyme was reached at a concentration of $0.6 \mathrm{~g} / \mathrm{L}$ of the enzyme solutions, $50^{\circ} \mathrm{C}$ and a reaction time of the enzyme of 40 minutes (Figure 2).

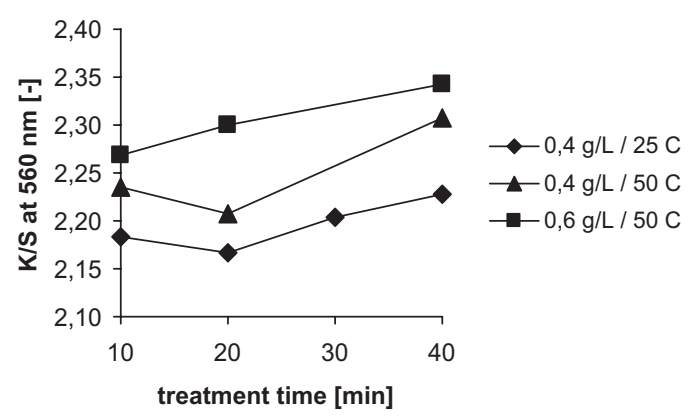

Fig. 2 - Color yield expressed in K/S in dependence on treatment time, temperature and catalase concentration.

\section{CONCLUSIONS}

The use of a commercial catalase for the elimination of hydrogen peroxide residues from cotton fabrics improved considerably the dyeing behavior and the color yield with a reactive bifunctional monofluortriazinyl dye. Similar results were observed by Tzanov et al. (2001a) for reactive dyes with a monochlortriazinyl or vinylsulfonic reactive group. The catalase can be applied after bleaching, directly in the dyeing bath. As a consequence of the decrease of the washing steps, water consumption and effluent vol- 
ume are reduced. The final product did not present any significant alterations in its physical and chemical properties. Compared with the chemical reducer and successive washes, the use of the catalase showed to be a viable alternative for textile processing.

\section{RESUMO}

O resultado do tingimento de tecido de algodão com corante reativo bifuncional foi signicativamente melhorado quando o tecido, após pré-alvejamento com peróxido de hidrogênio, foi tratado com enzima catalase para eliminar os resíduos de peróxidos. Comparado com processos utilizando um número variável de etapas de lavagens, com e sem o uso de agentes redutores comerciais, o consumo de água foi significativamente reduzido sem alterar a tonalidade final da cor.

Palavras-chave: catalase, pré-alvejamento com peróxido, tecidos de algodão, química têxtil, corantes reativos, tingimento.

\section{REFERENCES}

Andreaus J, Campos R, Gübitz G and Cavaco-Paulo A. 2000. Influence of Cellulases on Indigo Backstaining. Textile Res J 70: 628-632.

Bishop DP, Shen J, Heine E ANd Hollfelder B. 1998. J Textile Inst 89: 546.

Buschle-Diller G, El Mohgahzy Y, Inglesby MK and Zeronian SH. 1998. Effects of Scouring with Enzymes, Organic Solvents, and Caustic Soda on the Properties of Hydrogen Peroxide Bleached Cotton Yarn. Textile Res J 68: 920-929.
Cavaco-Paulo A. 1998. Processing Textile Fibres with Enzymes. K. E. Eriksson and A. Cavaco-Paulo, Eds. ACS Symp Ser 687: p.180.

Durán N AND Durán M. 2000. Enzyme Applications in the Textile Industry. Rev Prog Coloration 30: 41-44.

Heine E and Hocke H. 1995. Enzyme treatments for wool and cotton. Rev Prog Coloration Rel Topics 25: 57.

Pacheco AS. 1998. Tecnologia para Acabamento com Enzimas. Química Têxtil 50: 56-61.

Schмidt MG. 1995. Bleach Cleanup with Catalase. In: Int. Conf. Exhib AATCC, Philadelphia, p. 248-255.

Trotman ER. 1990. Dyeing and chemical technology of textile fibers, $6^{\text {th }}$ ed., Charles Griffin \& Company LTDA.

Tzanov T, Costa S, Guebitz GM and Cavaco-Paulo A. 2001a. Dyeing in catalase-treated bleaching baths. Color Technol 117: 1-5.

Tzanov T, Costa S, Guebitz GM and Cavaco-Paulo A. 2001b. Effect of temperature and bath composition on the dyeing of cotton with catalase-treated bleaching effluents. Color Technol 117: 166-170.

Uygur A. 1997. An overview of oxidative and photooxidative decolorisation treatments of textile waste waters. JSDC 113: 211-217.

UyGUR A. 2001. Reuse of decoulorized wastewater of azo dyes containing dichlorotriazinyl reactive groups using an advanced oxidation method. Color Technol 117: 111-113.

Vitolo M AND Filho JAR. 1995. Enzimas no Contexto da Síntese Orgânica. USP, São Paulo. 